Jurnal Riset Kesehatan, 9 (1), 2020, 78 - 82

DOI: $10.31983 /$ jrk.v9i1.5718

Jurnal Riset Kesehatan

http://ejournal.poltekkes-smg.ac.id/ojs/index.php/jrk

\title{
CORELATION OF COMPLETE MEDICAL INFORMATION WITH ACCURACY DIAGNOSIS CODE OF URINARY TRACT INFECTION AT SEBELAS MARET HOSPITAL
}

\author{
Linda Widyaningrum*) \\ Universitas Duta Bangsa Surakarta ; \\ Jln KH Samanhudi No 93 Sondakan Laweyan
}

\begin{abstract}
Accuracy Code Diagnosis is the accuracy of the diagnosis code based on ICD-10 by the coding officer on the medical record document by examining the results of the diagnosis written by doctors and medical personnel. This type of research is observational analytic with cross sectional approach. In this study the population used was inpatient medical record documents with a diagnosis of urinary tract infection as many as 229 . The sample used was 146 by using a simple random sampling technique. The percentage of accuracy of the diagnosis code of urinary tract infection in inpatient medical record documents at Sebelas Maret University Hospital was $129(88,36 \%)$ documents and $17(11,64 \%)$ inaccuracies of documents. The percentage of completeness of medical information from 146 documents studied was $78(53,42 \%)$ documents while the incomplete category was $68(46,58 \%)$ documents. The results of calculations using SPSS with the Chi Square statistical test results are 4.459 while the value of $p=0,035$ with an error level of 0,05 so that the value of $p<0,05$. The conclusion is corelatin the completeness of medical information with the accuracy of the urinary tract infection diagnosis code is rejected.
\end{abstract}

Keywords : Accuracy Code; Urinary Tract Infection Diagnosis; Inpatient Documents

\section{Introduction}

Medical information is used in coding ICD-10. Coding based on ICD-10 is the process of coding by using letters and numbers that represent data components that aim to ensure the accuracy of the chosen code representing the name of the diagnosis established by the doctor (Menkes, 2016). Accurate coding requires good cooperation between doctors and coders. Completeness of the medical record written by the doctor will greatly help the coders in providing the diagnosis code and the right course of action. According to clinical epidemiological research data reported $25 \%-35 \%$ of all adult women have experienced a Urinary Tract Infection (UTI). National Kidney and Urology Disease Information Clearinghouse (NKUDIC) also revealed that men are rarely affected by urinary tract infection or commonly referred to as urinary tract infections, but if exposed can be a serious

\footnotetext{
*) Correspondence Author (Linda Widyaningrum)
}

E-mail: linda_widya@udb.ac.id problem. Urinary tract infections are estimated to reach more than 7 million visits per year, around $40 \%$ of women will experience a UTI if only once in their lives.

The prevalence in the elderly ranges between $15 \%-60 \%$, the ratio between women and men is $3: 1$ (NKUDIC, 2012). According to the medical record index report of the top 10 diseases at Sebelas Maret University Hospital, the diagnosis of binary tract infection was ranked second. The researcher wants to examine the accuracy of the code seen on the entry and exit summary sheet and medical resume. Researchers also want to examine the completeness of medical information on the patient's medical record document which is seen from the results of supporting tests in the form of laboratory examination results, radiology results, and integrated patient development records. Researchers took research on the accuracy of the urinary tract infection diagnosis code because the case was included in the data of the top 10 inpatient inpatients at Sebelas Maret University 
Hospital. Researchers conducted a preliminary survey by taking samples of 10 documents for inpatient medical records with a diagnosis of urinary tract infection, from 10 documents that were examined there were 2 inaccurate medical records and 8 accurate documents, and 4 incomplete documents and 6 documents that were incomplete already complete. The purpose of this study was to determine the percentage of completeness of medical information in the diagnosis code of urinary tract infection in the inpatient medical record document at Sebelas Maret University Hospital determine the percentage of accuracy of the urinary tract infection diagnosis code at Sebelas Maret University Hospital and determine the relationship between the completeness of medical information with the accuracy of the urinary tract infection diagnosis code at Sebelas Maret University Hospital.

\section{Method}

The type of research used is analytic observational. The research instrument used in the study was a checklist, interview guidelines, SPSS and observation guidelines. The population used in this study is outpatient medical record documents with a diagnosis of urinary tract infection in 2019, amounting to 229 medical record documents and 146 documents with Simple Random Sampling that is, each member or unit of the population has the same opportunity to be selected as a sample. Statistical data analysis with Chi square test.

\section{Result and Discussion}

The results of the analysis of the percentage of completeness of medical information are 78 $(53.42 \%)$ and the incomplete category is 68 $(46.58 \%)$, for more details, presented in the form of a pie diagram 1 .

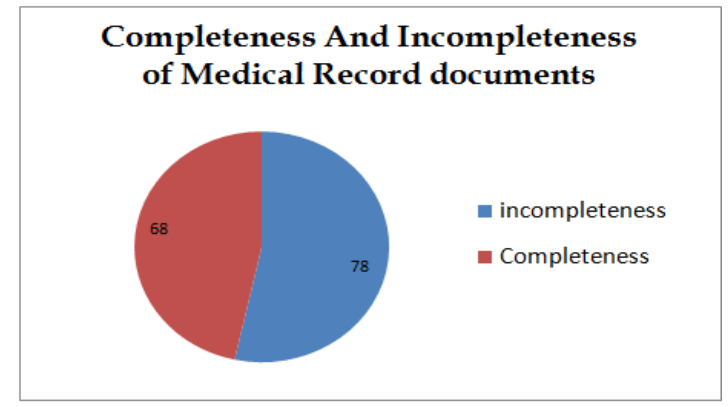

Diagram 1. Completeness And Incompleteness Of Medical Record Documents

The results of the percentage of accuracy and inaccuracy of the urinary tract infection diagnosis code are $129(88,36 \%)$ accurate medical record documents and $17(11,64 \%)$ inaccurate medical record documents from 146 inpatient medical record documents studied. Presented in the form of a pie diagram 2 .

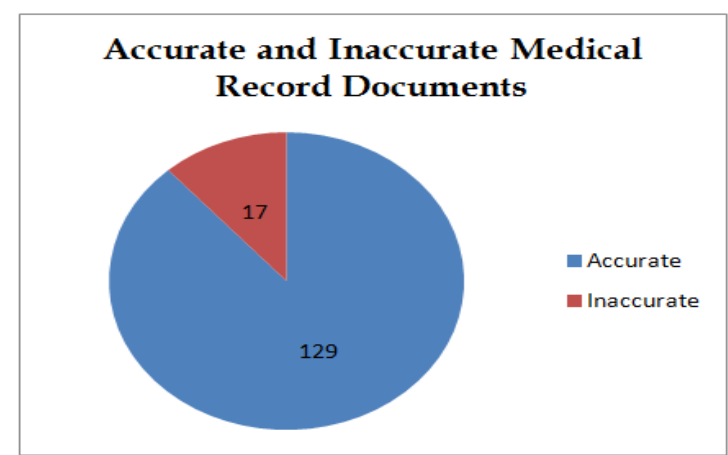

Diagram 2. Accurate and Inaccurate Medical Record Documents

Determination of the relationship of the completeness of medical information with the accuracy of the urinary tract infection diagnosis code N39.0 with statistical tests using the Chi-Square formula can be seen in the table 1 .

Table 1. Statisticals Test

\begin{tabular}{|c|c|c|c|c|c|c|}
\hline No & & Value & df & $\begin{array}{l}\text { Asymp. Sig. } \\
\text { (2-sided) }\end{array}$ & $\begin{array}{l}\text { Exact Sig. } \\
\text { (2-sided) }\end{array}$ & $\begin{array}{l}\text { Exact Sig. } \\
\text { (1-sided) }\end{array}$ \\
\hline 1 & Pearson Chi-Square & $4,45 a$ & 1 & 0,03 & & \\
\hline 2 & $\begin{array}{l}\text { Continuity } \\
\text { Correctionb }\end{array}$ & 3,43 & 1 & 0,06 & & \\
\hline 3 & Likelihood Ratio & 4,53 & 1 & 0,03 & & \\
\hline 4 & Fisher's Exact Test & & & & 0,04 & 0,03 \\
\hline 5 & $\begin{array}{l}\text { Linear-by-Linear } \\
\text { Association }\end{array}$ & 4,42 & 1 & 0,03 & & \\
\hline 6 & $\mathrm{~N}$ of Valid Cases & 146 & & & & \\
\hline
\end{tabular}


Based on the results of calculations using SPSS with Chi Square statistical test results obtained Chi Square calculation is 4,45 while the value of $p=0,03$ with an error level of 0,05 so the value of $p<0,05$. It can be concluded that Ho was accepted and Ha was rejected, meaning that there was no relationship between the completeness of medical information and the accuracy of the urinary tract infection diagnosis code in the inpatient medical record document at Sebelas Maret University Hospital. The incompleteness of medical information can affect the quality of medical record documents as well as can influence in determining the accuracy of the code. This is consistent with the results of research by Wariyanti (2013), the completeness of medical information on each medical record form has an important role in determining an accurate code through a diagnosis established by a doctor. Reinforced with Hatta's statement (2013), the important thing that must be paid attention to by medical record personnel in maintaining the quality of medical record documents is the completeness of medical information related to the patient's disease history that starts from the beginning of treatment until the patient returns from the hospital, contains about physical examination and other supporting examination. In addition, medical record personnel must carry out classification and codefication of the disease to create accuracy in the diagnosis code.

The complete medical information research that was investigated included a summary of entry and exit, integrated patient development records, radiology results, laboratory results and medical resumes. This refers to Permenkes No. 269/Menkes/Per/III/2008 concerning medical records stating that the requirements of inpatient medical records contain at least the patient's identity, examination, diagnosis, approval of action (if any), action or treatment and services that have been provided to patients.

The accuracy of the diagnosis code is the provision of an appropriate code based on the provisions of ICD 10. Disease codes can be classified into accurate and inaccurate codes. Accurate code is the determination of the right code, complete and in accordance with ICD 10. To get an accurate code must see medical information and pay attention to the instructions in ICD 10.

Based on the results of research conducted there were $129(88,36 \%)$ accurate medical record documents and $17(11,64 \%)$ medical record documents are not accurate. The inaccuracy of the urinary tract infection diagnosis code in the inpatient medical record document is not coded, which is $16(94,12 \%)$ documents and is inaccurate due to incorrect code writing in 1 (5,88\%) document. This is because the coding officer does not provide code on the entry and exit summary sheet.

According to the Indonesian Ministry of Healt, the factors that influence the accuracy of the code, the speed and accuracy of the coding of a diagnosis are very dependent on the executor who has the medical record file, namely:

\section{a. Medical personnel}

Determination of a patient's diagnosis is an obligation, rights and responsibilities of the doctor (medical personnel), because it must fill out the diagnosis that is in the medical record completely and clearly in accordance with the instructions contained in the book ICD-10.

\section{b. Medical record personnel as the coder}

Medical record personnel as a provider of code are responsible for the accuracy of the code of a diagnosis that has been determined by medical staff. Therefore, for matters that are unclear or incomplete before the code is established, first communicate with the doctor who made the diagnosis.

\section{c. Other health workers}

The smoothness and completeness of medical records in outpatient and inpatient installations requires the cooperation of medical personnel and other health workers. Other health workers in question include laboratory workers, radiology officers, physiotherapy officers, and others

This study is relevant to the Pujihastuti study finding (2014) which shows that there is no significant relationship between the completeness of medical information and the accuracy of the diagnosis code for carcinoma mammae in the inpatient medical record document at RSUD Dr. Moewardi with a $p$ value $>0,05$.

Completeness of medical information and accuracy of diagnosis codes is very important and related, if medical information in a medical record document is incomplete, the resulting diagnosis code becomes inaccurate. Factors causing the incompleteness of medical record documents are the lack of awareness of the importance of completing medical record documents so that many doctors and other health workers ignore the completeness of medical information. The incompleteness of medical 
information is very influential and inhibiting for the coding officer because the coding officer must find a doctor and confirm the diagnosis to get an accurate code. Medical record personnel as the giver of the code are responsible for the accuracy of the code of a diagnosis that has been determined by medical personnel, therefore unclear or incomplete information needs to be communicated first to the doctor in charge before the diagnosis code is established.

\section{Conclusion and Sugestion}

The limitation of this study is that it takes a long time to collect samples because it requires medical record documents. Completed medical information from 146 medical record documents studied, there were $78 \quad(53,42 \%)$ complete documents and 68 (46,58\%) incomplete documents.

The accuracy of the diagnosis code of urinary tract infection in inpatient medical record documents at Sebelas Maret University Hospital is $129(88,36 \%)$ accurate documents and 17 $(11,64 \%)$ documents are inaccurate.

The results of calculations using SPSS with Chi Square statistical test results obtained Chi Square calculation is 4,459 while the value of $p=$ 0,035 with an error level of 0,05 so the value of $p$ $<0,05$. The conclusion that Ho was accepted and Ha was rejected, meaning that there was no relationship between the completeness of medical information with the accuracy of the urinary tract infection diagnosis code in the inpatient medical record document at Sebelas Maret University Hospital.

The standart Opresional Procedure (SOP) should be made about evaluating the completeness of medical record documents in order to minimize incomplete documents. It is better for the coder to be more careful in writing diagnosis codes in medical record documents so that they can maintain the accuracy of reporting information.

\section{Acknowledgements}

Acknowledgements to the chairman of the education and training center sebelas Maret hospital and chairman of LPPM Poltekes Kemenkes Semarang which has provided the opportunity to publish this scientific journal.

\section{References}

Hatta G R. 2014. Pedoman Manajenen Informasi Kesehatan di Sarana Pelayanan Kesehatan
Edisi revisi 3. Jakarta: UI Press.

Haryono, R. 2012. Keperawatan Medical Bedah : Sistem Perkemihan. Rapha Publishing.Yogyakarta.

IDAI. 2011. Unit Kerja Koordinasi (UKK). Nefrologi, Jakarta.

Menteri Kesehatan Republik Indonesia. Peraturan Menteri Kesehatan Republik Indonesia Nomor. 269/ MENKES/ PER/ III/ 2008. Tentang Rekam Medis. Jakarta : Mentri Kesehatan Republik Indonesia.

Menteri Kesehatan Republik Indonesia. Peraturan Menteri Kesehatan Republik Indonesia Nomor. 76/ MENKES/ PER/ III/ 2016. Tentang Pedoman Indonesian Case Base Group. Jakarta : Mentri Kesehatan Republik Indonesia.

Microsoft Excel 2007. 2007. Membangun Rumus dan Fungsi. Edisi Pertama. Yogyakarta: Andi Offset.

National Kidney and Urologic Disease Information Clearinghouse (NKUDIC). 2012. Urinary Tract Infection In Adult. http://kidney.nidkk.nih.gov/kudiseas e/pubs/utiadult. Diakses 4 Febuari 2019.

Notoatmodjo, S. 2014. Metodologi Penelitian Kesehatan. Jakarta: PT Rineka Cipta.

Pujihastuti, A dan Sudra R I 2014. Hubungan Antara Kelengkapan Informasi Medis Dengan Keakuratan Kode Diagnosis Pada Dokumen Rekam Medis Rawat Inap.Jurnal Manajemen Informasi Kesehatan. ISSN : 2337-585X: Vol.3 : No.1

Purnomo, B. B. 2014. Dasar-dasar urologi. Edisi Ketiga.Malang: CV Sagung Seto.

Riyanto, A. 2011. Aplikasi Metodologi Penelitian Kesehatan. Yogyakarta: Nuha Medika.

Sabarguna. 2008. Quality Asurance Pelayanan Rumah Sakit. Jakarta : CV Sagung Seto.

Saryono dan Mekar D A. 2013. Metodologi Penelitian Kualitatif dan Kuantitatif Dalam Bidang Kesehatan. Yogyakarta: Nuha Medika.

Siregar, S. 2010. Statistik Deskriptif untuk Penelitian. Jakarta: PT Raja Grafindo Persada.

Sudra RI. 2014. Rekam Medis. Tangerang Selatan: Universitas Terbuka.

Sugiyono. 2015. Metode Penelitian Manajemen. Bandung: Alfabeta.

Wariyanti AS, 2013. Hubungan Antara Kelengkapan Informasi Medis Dengan Keakuratan Kode Diagnosis Pada Dokumen Rekam Medis Rawat Inap Di Rumah Sakit Umum Daerah 
Jurnal Riset Kesehatan, 9 (1), 2020, 82 - 82

DOI: $10.31983 /$ jrk.v9i1.5718

Kabupaten Karanganyar Tahun 2013

World Health Organization. 2010. International Statistical Classification of Diseases and Related Health Problem Tenth Revision. Volume 1. Ganeva: WHO.

2010. International Statistical Classification of Diseases and Related Health Problem
Tenth Revision. Volume 2. Ganeva: WHO.

2010. International Statistical Classification of Diseases and Related Health Problem Tenth Revision. Volume 3. Ganeva: WHO. 